\title{
ROLE OF MAN-MADE SYSTEMS IN CLIMATE CHANGE ON THE PLANET: WAYS TO SOLVE PROBLEMS
}

Leonov V. Ye.

\section{INTRODUCTION}

Man-made systems include the most significant transport industry that affects climate change on the planet. World maritime and inland waterway transport consume a significant amount of marine fuel - 1 billion tons per year and, accordingly, emit more than 3 billion tons of carbon dioxide, the main component of "greenhouse» gases, with the exhaust gases of Ship Power Plants (EG SPP). During the operation of ships, waste is generated, which can be conditionally divided into two types: 1) material; 2) energy (Fig. 1).

Impact of ships on the environment

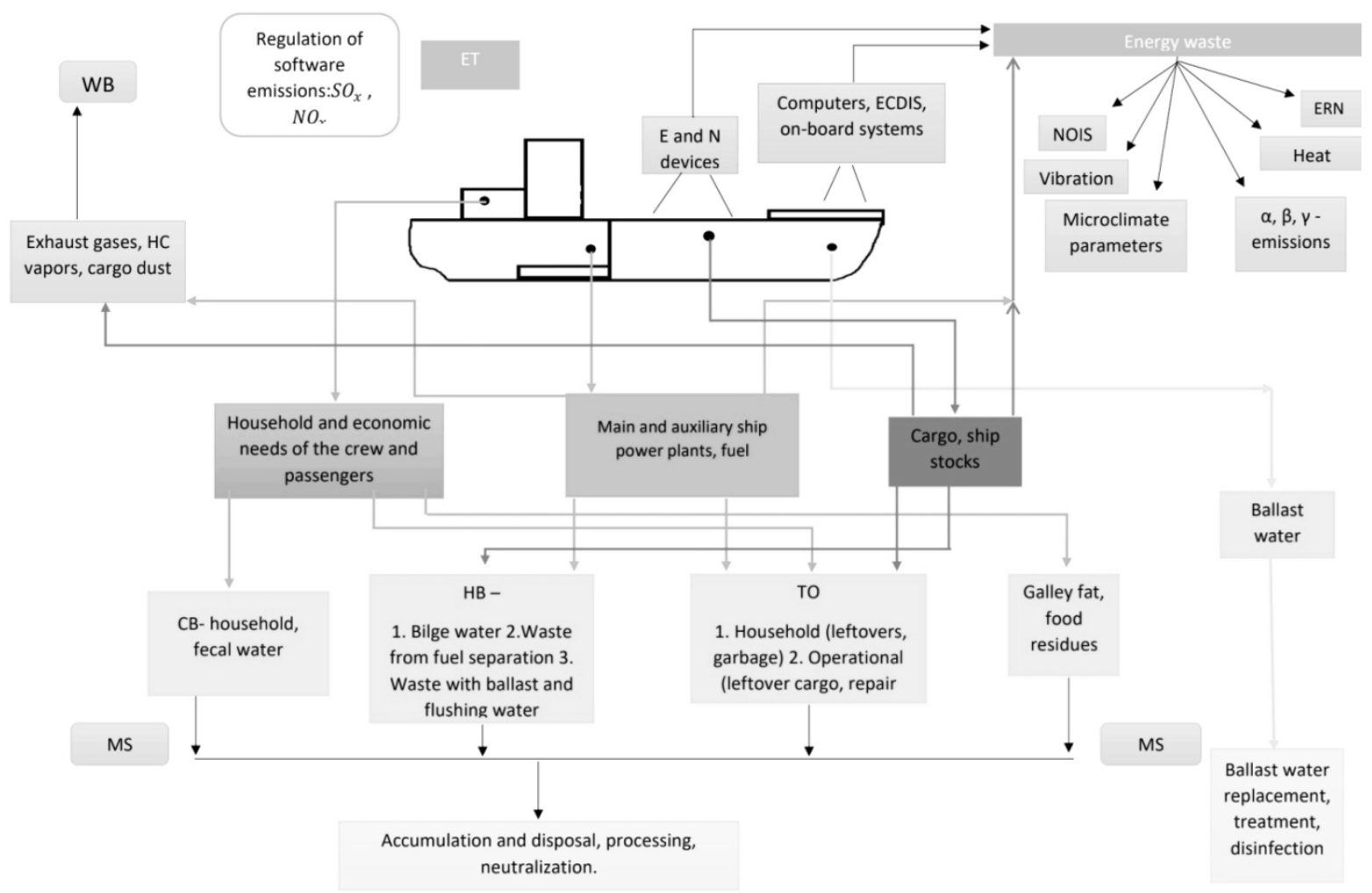

Figure 1-Impact of ships on the environment 
Legend: MS-marine environment; WB-air basin; ET-energy waste; $\mathrm{E}$ and $\mathrm{H}$-elektro-navigation and radio navigation devices; ECDIS-electronic cartographic navigation information system.

Material shipboard wastes include gaseous (EG SPP, vapors, dustoftransported goods), liquid - ship waste, bilge oily water, solid operational and domestic. Energy waste should include noise, vibration, excess heat, electromagnetic fields, radioactive radiation, etc. A special place, as a dangerous and harmful pollutant on a ship, is assigned to ship's ballast water .

The technogenic systems, in particular marine transport, are the basic "suppliers" of components of "greenhouse" gases, such substances and connections as dioxide of carbon, hydrocarbons, nitrous oxide, organic mineral dust, soot, pairs of water behave to that.

Opinions of scientists and experts through question of planetary "greenhouse" effect are diametrically opposite. And it, in our view, under itself has basis. Really, to answer a simple question, whether there is a "greenhouse" effect on a planet or he is not present, necessary to have the reliable materials got as a result of research works. To conduct experiments in the global scale of planet and space in the direction of study of "greenhouse" effect on the modern stage is not possible.

Therefore this work is conducted on the offered hypothetical models. The methods of mathematical design, on the basis of that preferentially drawn conclusion about of presence or nonpresence of "greenhouse" effect on Earth, are used in calculation researches. A lack of any offered models of "greenhouse" effect is the absence and/or impossibility of verification of them on adequacy in the real terms of experiment on a planet and in space.

The idea of the mechanism of the "greenhouse" effect was first outlined in 1827 by Joseph Fourier in the article "Note on the temperatures of the globe and other planets", in which he considered various mechanisms of the formation of the Earth's climate, while he considered them as factors affecting the overall heat balance Earth, (heating by solar radiation, cooling due to radiation, internal heat of the Earth), and factors affecting heat transfer and temperatures of climatic zones (thermal conductivity, atmospheric and oceanic circulation).

In works ${ }^{1}$ the detailed analysis over of possible reasons of origin and consequences of "greenhouse" effect is brought.

\footnotetext{
${ }^{1}$ Леонов В.Е., Ходаковский В.Ф., Куликова Л.Б. Монография: Основы экологии и охрана окружающей среды./Под редакцией доктора технических наук, профессора В.Е. Леонова ./ Херсон:Херсонская государственная морская академия. 2010.-352 с.; Леонов В.Е., Ходаковский А.В. Учебное пособие: «Экология и охрана окружающей среды»./ Под редакцией доктора технических наук, профессора В.Е. Леонова ./ Херсон:Херсонская государственная морская академия./ 2016.-348 с.
} 
Scientists from the Californian University in Irwine (USA) reported about the threat of flood for 400 million persons from a rise in temperature, "greenhouse" effect ${ }^{2}$.

The melting glaciers of Greenland considerably heaved up the level of the World ocean - for two months he increased on 2,2 $\mathrm{mm}$. Reason, melting became that a more than 600 milliard of tons of ice. These processes were accompanied by a too warm summer 2019 year. The last year was most warm in all history of Arctic. It was shown by calculations, that ice in Greenland began to melt sevenfold quicker, than it was in 1990th.

The content of carbon dioxide in the Earth's atmosphere in August 2019 increased by three points relative to the same indicator in 2018, which means that humanity cannot reduce $\mathrm{CO}_{2}$ emissions into the atmosphere and slow down global warming, said the National Aeronautics and Space Administration (NASA, USA) ${ }^{3}$. The specialists of NASA confirmed exactness of the recently obtained data on the temperature of air layer at the surface of sea, dry spell, and ice sheet by means of satellite Aqua, testifying to the rapid global warming (information over is brought in a press-release on Eurek Alert). According to the model calculations of scientists, if no measures are taken to reduce greenhouse gas emissions, then by the end of the $21 \mathrm{st}$ century the temperature of seawater in the upper layer $2,000 \mathrm{~m}$ thick will rise by $0.78^{\circ} \mathrm{C}$. It will promote the level of world ocean only due to thermal by volume expansion on additional a $30 \mathrm{~cm}$ in addition to getting up of level of marine aquatorium of coastline from a melting glaciers. The increasing of temperature of marine environment and air pool will provoke more severe storms, hurricanes and extreme fallouts.

The scientists of Toronto University (Canada) found out that rise in temperature of climate in a region Yukon on the north-west of Canada became the strongest after more, than ten thousand years (information over is brought in a press-release on Eurek Alert). Researchers believe that warming on Earth could destabilize permafrost, leading to even greater emissions of methane and carbon dioxide, the main components of «greenhouse» gases.

In works ${ }^{4}$ scientists propose to spray aerosols into the atmosphere of the air basin so as to reduce warming by $50 \%$. The idea itself is not new, but it

\footnotetext{
${ }^{2}$ Изменение климата достигло катастрофических масштабов. 2021. https://news.rambler.ru/ tech/45673808izmenenie-klimatadostig

${ }^{3}$ Содержание углекислого газа в атмосфере Земли значительно выросло. Деловая газета “Взгляд”.2019.

${ }^{4}$ Hensher DA, Faqhimnia V. Green logistics and Transportation. Greening of Industry Networks Studies 4. Springer International Publishing Switzerland. 2015.-Vol.65(3), p. 131-145.; Thalis ZisH., Angeloudis and Michel G.H. Bell. Economic and Environmental Trade-Offs in Water Transportation. Springer International Publishing Switzerland. 2015.-Vol.65(3). p.159-165.; Романов Е.В.,Лелецкий А.В.,Лабунин К.А.
} 
has been criticized. Researchers have created a geoengineering model for targeting the Earth's climate with aerosol spraying in the stratosphere. In the model of scientists, sulfur dioxide was considered as an aerosol. It is noted that this measure will not solve the problem of global warming in general, but can only be considered as part of an integrated approach.

As a comment of authors of this article to works ${ }^{5}$ :

1) from where to take in the enormous amounts of planetary scale dioxide of sulphur as a protective aerosol?

2) dioxide of sulphur in the stratospheric layer of atmosphere will be exposed to oxidization by an active oxidant by ozone to the sulphuric anhydride, and sulphuric anhydride at co-operating with the pairs of water, contained in atmospheric air, will result in formation of sulphuric acid.

As a result, not deciding the problem of the global warming of Earth, this suggestion will lead and to strengthening two other global problems to destruction of "ozone layer" of planet and intensification of "acid" rains.

The transport sector accounted for $22 \%$ of global carbon dioxide emissions in $2010^{6}$, including the shipping sector in 2013 accounting for $2.2 \%$ of global $\mathrm{CO}_{2}$ emissions compared to $2.7 \%$ of $\mathrm{CO}_{2}$ emissions in $2008^{7}$.

In work ${ }^{8}$ materials on carbon dioxide emissions from public transport are given: in Sydney (Australia), the level of carbon dioxide emissions per passenger-kilometer was, g: 188 for an average car, 120 for a bus, 105 for a train ride, 171-by light rail. $\mathrm{CO}_{2}$ emissions from each chain were approximated by the sum of emissions from all stages of the trip.

Results - one cannot do without reducing technogenic (manmade systems) emissions of components of "greenhouse" gases, one cannot solve the global problem of climate warming on planet Earth".

\footnotetext{
Парниковый эффект: принципы, последствия, способы оптимизации. Орел:Вестник Орловского государственного университета имени И.С. Тургенева. 2019. С. 13-18. URL- cyberleninka.ru.

${ }^{5}$ Там само

${ }^{6}$ Lee Chapman. Transport and climate change: a review. Journal of Transport Geography.2007.- Vol.15, Iss.5, P. 354-367. doi:10.1016/j.jtrangeo.2007.11.008; Klaus Eisenack, Rebecca Stecker, Diana Reckien \& Esther Hoffmann .Adaptation to climate change in the transport sector: a review of actions and actors. Mitigation and Adaptation Strategies for Global Change. 2012.- Vol 17, p. 451-469

${ }^{7}$ MEPC 65/INF.17. IMO Model Course on Energy-Efficient Operation of Ships. London: World Maritime University. 2013.61 p.

${ }^{8}$ Изменение климата достигло катастрофических масштабов. 2021. https://news.rambler.ru/tech/45673808izmenenie-klimatadostig

${ }^{9}$ H.-N. Su, I.M.Moaniba. Does innovation respond to climate change? Empirical evidence from patents and greenhouse gas emissions. Technological Forecasting and Social Change. 2017. Vol. 122, P. 49-62. doi:10.1016/j.techfore.2017.04.017; V.Ramanathan, Y.Feng. Air pollution, greenhouse gases and climate change: Global and regional perspectives. Atmospheric Environment 2009.-Vol. 43, Issue 1, P. 37-50. DOI: 10.1016/j.atmosenv. 2008.09.063; Леонов B.Е., Чернявский В.В. Монография:Современные методы исследований и обработки экспериментальных данных / Под редакцией доктора технических наук, профессора В.Е. Леонова. / Херсон:Херсонская государственная морская академия. / 2020. 520 с. ISBN 978-966-2245-60-8.
} 


\section{The problem's prerequisites emergence and the problem's formulation}

By us, in order of discussion, for the last 60 years an analysis ${ }^{10}$, calculation researches, is conducted on the accumulation of dioxide of carbon - basic component of "greenhouse" gases on a planet. This period of time was accepted coming from that exactly he is characterized by the most intensive consumption of hydrocarbon raw material of unrenewable character (oil, natural gas, coal, slates) and, accordingly, most emission of dioxide of carbon in an atmosphere and environment. The results of researches are shown on a Fig. 2.

On the Fig. 2 curve 1 is total anthropogenic $\mathrm{CO}_{2}$ accumulation; curve 2 is anthropogenic accumulation of $\mathrm{CO}_{2}$ in the atmospheric air; curve 3 is average annual increase in atmospheric air temperature; curve 4 is natural accumulation of $\mathrm{CO}_{2}$ in the atmospheric air.

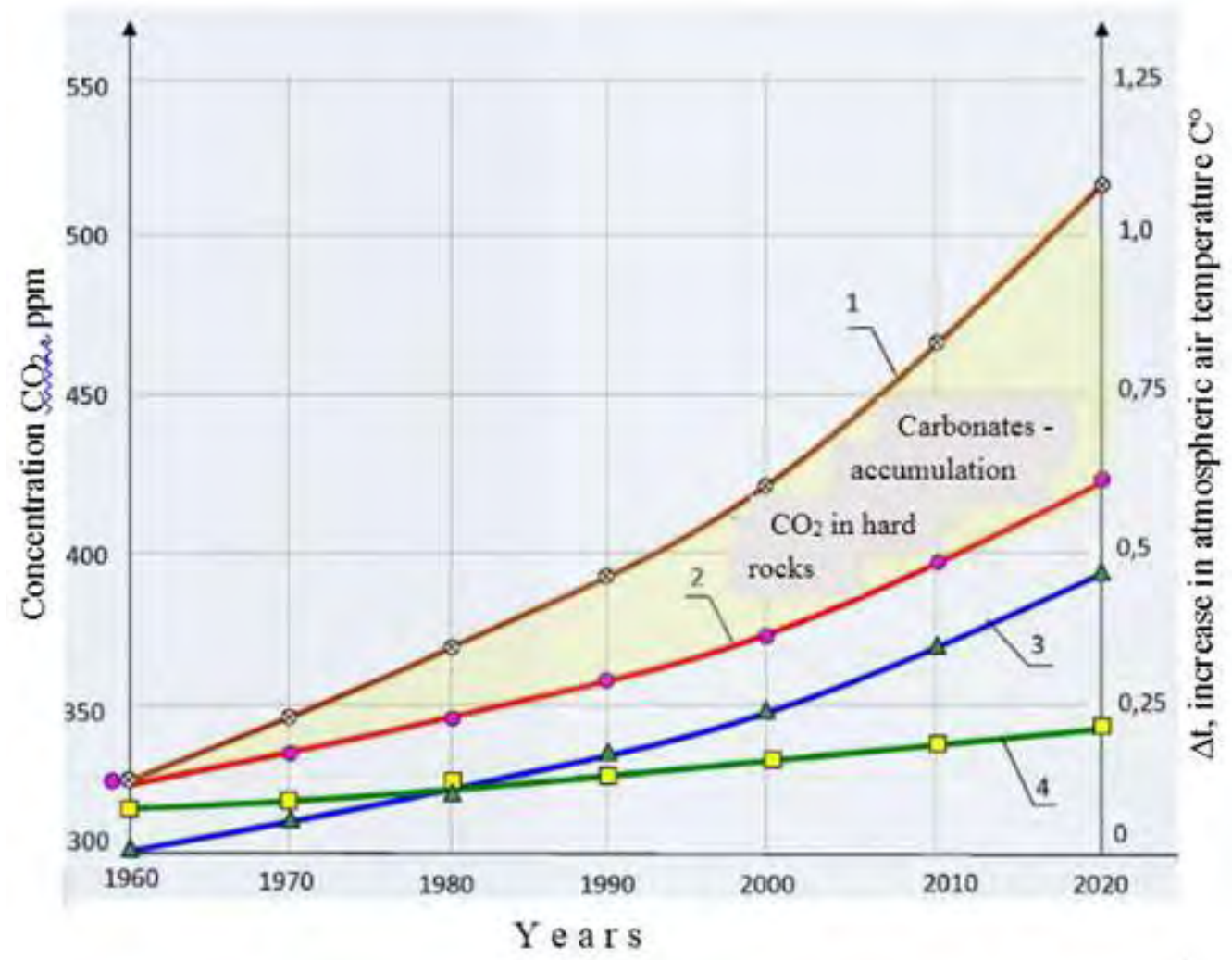

Figure 2 - Change in the concentration of carbon dioxide and the average annualincrease in atmospheric air temperature depending on time (years).

\footnotetext{
${ }^{10}$ Leonov V., Gurov A. GREENHOUSE EFFECT. FICTION or RESULT of the PROLONGED ACTION of the TECHNOGENIC SYSTEMS. The Scientific Heritage : Hungary. 2021.- Vol. 1(60), p. 29-39. DOI: 10.24412/9215-0365-2021-60-1-29-29-39. https://www.elibrary.ru/item.asp?id=44726893
} 
Legend: ppm is parts per million, $\Delta \mathrm{t}$ is the average annual increase in atmospheric air temperature, ${ }^{\circ} \mathrm{C}$.

Carbon dioxide, regardless of the nature of its formation, can accumulate in shells, solid rocks with the formation of carbonates, dissolve in seawater, participate in photosynthesis atmospheric air temperature depending on time (years) reactions, and excess of carbon dioxide accumulates in the atmospheric air.

The dynamics of an intensive increase in the total concentration of carbon dioxide in the environment (Curve 1, Fig. 2) is fully consistent with the intensive consumption of hydrocarbons over the same period of time. Curve 2 (Fig. 2) characterizes the growth dynamics of the concentration of carbon dioxide in the atmospheric air, which includes two sources of carbon dioxide formation - anthropogenic (predominant) and natural (Curve 4, Fig. 2). We had found that curve 2 (increasing of $\mathrm{CO}_{2}$ concentration in the atmospheric air) and curve 3 (average annual increasing of atmospheric temperature over the same period of time) are practically parallel (congruent), which indicates that the accumulation of $\mathrm{CO}_{2}$ in atmospheric air is related to the average annual increasing of atmospheric air temperature. And this, in turn, determines the role of carbon dioxide as the main component of "greenhouse" gases that stimulate the "greenhouse" effect, leading to a warming of the climate on Planet.

Interesting, in our opinion, is the nature of the change in the natural concentration of $\mathrm{CO}_{2}$ in the atmospheric air, why there is a monotonic increase in the concentration of $\mathrm{CO}_{2}$ over the analyzed period of time. It can be assumed with a high degree of certainty that over the indicated period of time, as a result of human actions and technogenic systems, the organic base for the photosynthesis reaction (forests, blue-green algae) is depleted, inhibited, which leads to a decrease in the productivity of the photosynthesis reaction and, as a consequence, to a decrease in the mass of carbon dioxide involved in the photosynthesis reaction. Excess natural carbon dioxide accumulates in the atmospheric air, which is consistent with the course of curve 4 (Fig.2).

It should be noted that the results of computational and analytical calculations carried out by us ${ }^{11}$ correspond to the data on the accumulation of carbon dioxide obtained by Japanese researchers (Main Meteorological

${ }^{11}$ Leonov V., Gurov A. GREENHOUSE EFFECT. FICTION or RESULT of the PROLONGED ACTION of the TECHNOGENIC SYSTEMS. The Scientific Heritage : Hungary. 2021.- Vol. 1(60), p. 29-39. DOI: 10.24412/9215-0365-2021-60-1-29-29-39. https://www.elibrary.ru/item.asp?id=44726893 
Administration of Japan, NHK TV channel). The concentration of carbon dioxide in the atmosphere around Japan has become the highest during the observation period (2020-2021), which is carried out at three points in the northeast of the island of Honshu and on two remote islands in the southwest and east of Japan. The average indicators for 2020 were, respectively, $416.3 \mathrm{ppm}, 417.2 \mathrm{ppm}, 414 \mathrm{ppm}$. This is the highest $\mathrm{CO}_{2}$ level ever recorded since 1987. Meteorologists record a tendency towards an increase in the concentration of $\mathrm{CO}_{2}$ in the atmosphere. This is despite the decrease in $\mathrm{CO}_{2}$ emissions amid a decrease in production in Japan due to the coronavirus. Scientists note that the concentration of $\mathrm{CO}_{2}$ in the Earth's atmosphere is constantly increasing, and this leads to an increase in temperature and climate change. It should be noted that the practical data obtained recently by Japanese researchers sufficiently and fully correspond to the data obtained by us by calculation and analytical methods, as in terms of the $\mathrm{CO}_{2}$ accumulation figures - 414-417.2 ppm. and according to the general conclusion about the interrelation of the average temperature of atmospheric air and the accumulation of $\mathrm{CO}_{2}$ in the atmosphere (Fig. 2) ${ }^{12}$.

Based on the foregoing about the technogenic prerequisites for the emergence and intensification of the "greenhouse" effect, it is possible to propose a "scenario" of the impact of planetary climate change on the environment, ecosystems, biota, biome, biosphere, and humans (Fig. 3).

The certainly offered model (Fig.3) has hypothetical character, but in her basis indirect confirmations of the climatic phenomenon lie from data of change of some meteorological parameters of environment for the long period of time.

In 2015 the international climatic summit of COP-21 took place in Le Bourget (France), that was sanctified to the problem of rise in temperature of climate on a Planet and development of ways of overcoming of this crisis. More than 137 states of the world signed final Protocol of this summit.

The USA is the most meaningful consumer of hydrocarbon raw material of unrenewable character and separate countries the less meaningful in a plan consumptions of hydrocarbon raw material did not sign final Protocol of climatic summit, releasing itself from financial expenses, nature protection measures. It follows from this that greater part of the states of the world is disturbed by the global warming and his consequences.

${ }^{12}$ Концентрация $\mathrm{CO}_{2}$ в атмосфере вокруг Японии побила рекорд. Российская газета. 30.03.2021. 
In Kyoto and Parisian Protocols on issue of «greenhouse» effect on a Planet a Shipping and Aviation were not plugged into final formulation of Agreement $^{13}$.

International Marine Organization, International Organization of Civil Aviation, made enough an effort, that this error never repeated in future. Both these international organizations draw line on the change of eco law in part of toughening of requirements to emitters of the technogenic systems, including the Shipping and Aviation, on the basic components of «greenhouse» gases.

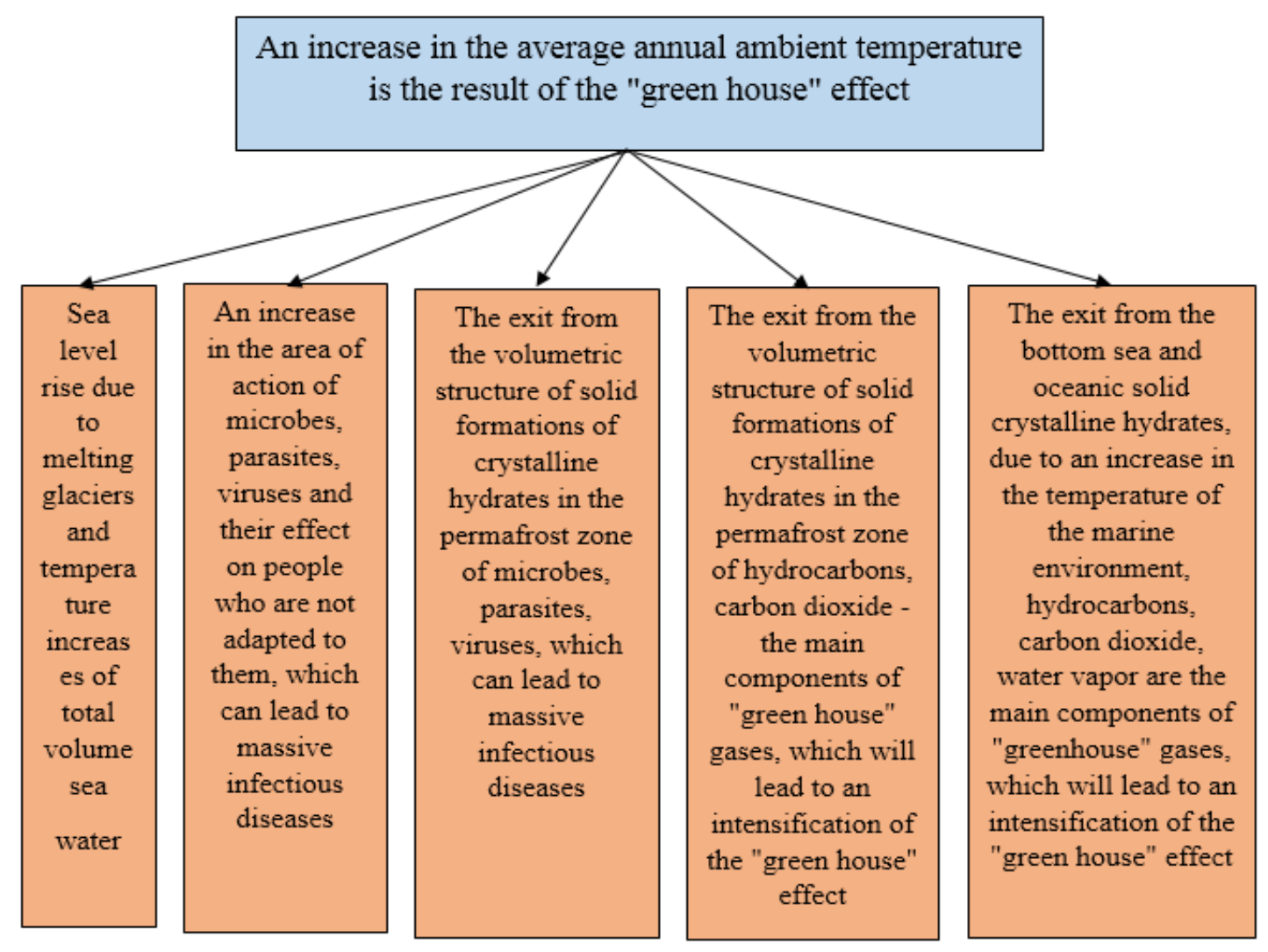

\section{Figure 3. The impact of an increase in the average annual temperature of the environment on the negative impact on ecosystems, biota, biomes, biosphere, humans}

13 Леонов В.Е., Ходаковский А.В. Учебное пособие: «Экология и охрана окружающей среды»./ Под редакцией доктора технических наук, профессора В.Е. Леонова ./ Херсон:Херсонская государственная морская академия./ 2016.-348 с.; Леонов В.Е., Чернявский В.В. Монография:Современные методы исследований и обработки экспериментальных данных / Под редакцией доктора технических наук, профессора В.Е. Леонова ./ Херсон:Херсонская государственная морская академия./ 2020.-520 с. 
It is necessary to mark that some Shipping and Aviation Companies are fully satisfied with that Agreement «went round them a side», as they fear additional material and financial charges on introduction of measures with the purpose of providing of the ecological safety related to the risk of intensification of «greenhouse» effect.

It should be noted that certain steps on business of defence of environment are nevertheless done. For example, for the sea and river vessels an additional certificate is entered on protecting of air space from contamination from ship engines, that is IAPP - International Air Pollution Prevention Certificate. Fulfillment of requirements of this Certificate by sea and river vessels undoubtedly brings the contribution to defence of ecology.

"A navigation needs some progressive eco law, - J. Carnerap Bang considers, senior expert on a climate in the Danish company Maersk Group - it must be universal, independent of flag and controlled by International Marine Organization. Conception of COP-21 must become a starting point for his making. First, in the preliminary variant of the Parisian agreement COP-21, 200 countries-participants worked on that, the Navigation and Aviation were mentioned, but this division of Agreement was abolished afterwards. It is necessary to mark that this Division did not contain concrete binding prescripts, just appeal to pay attention to problems of maritime and aviation vessels, but even in such kind could have influence on both industries" $"$.

Really, this just professional's opinion, responds conception of ecological safety on the whole, the Shipping and Aviation are in the first ten on a contribution to the "greenhouse" effect and integral contamination of planet, as a result of functioning of the manmade systems.

From 1990 to 2010 mass of emission of harmful toxic components and connections in Aviation increases on $80 \%$, and in a Shipping - on $40 \%$.

Rapid development of these industries of the manmade system can increase this contribution to the "greenhouse" effect to $40 \%$ in general balance even to 2050 .

So insolvency of ignoring of Shipping and Aviation in a rise of temperature of climate on Earth.

Besides material wastes, the Shipping and Aviation distinguish the considerable level of energy wastes - thermal, noise, vibration, electromagnetic fields, ultrasonic and infrasonic radiations, radio

14 Tам само 
frequencies of all levels and spectrums, satellite navigational, radar and radio contamination.

«A Parisian agreement will be specified and finished off, - considers P. Khinchliff, Secretary general of the International Chamber of Shipping (ICS). - I am quite sure that on some stage we will carry the opinion to the countries-founders and will enter a necessary to us paragraph in a document».

\section{Ways to solve the global problem of the "greenhouse" effect.}

In accordance with the analysis and calculations of marine cargo transportation conducted by us a modern marine transport expends an about 1 billion tons per year of hydrocarbon ship fuel, that corresponds to emission an about 3,2 billion tons per year of carbon dioxide.

It is necessary to mark that in 2019 the total emissions of dioxide of carbon - result of action of the manmade systems is made 40 billion tons. At the same time only from a Shipping, including ports and port facilities, the emissions of carbon dioxide made an about 4,5 billion tons per year.

Thus, deposit on the whole Shipping industries as manmade system in a general "greenhouse" effect (on dioxide of carbon) is $11,3 \%$. Possible to assume that in an Aviation approximately the same size on a contribution to the "greenhouse" effect. In the total on the Shipping and Aviation part in a general "greenhouse" effect is more than $22 \%$, and with it it is necessary to be considered at prognostication of development of intensity of "greenhouse" effect on a Planet.

Indeed, the intensity of sea freight traffic increases from year to year, which follows from Figure 4, obtained on the basis of processing satellite information.

To eliminate emission of components of "greenhouse" gases - dioxide of carbon, hydrocarbons, mineral dust, soot is impossible when use of hydrocarbon materials.

On the basis of our calculation researches it is possible to establish executed, that emission of dioxide of carbon is a consequence of processing of hydrocarbon material. 


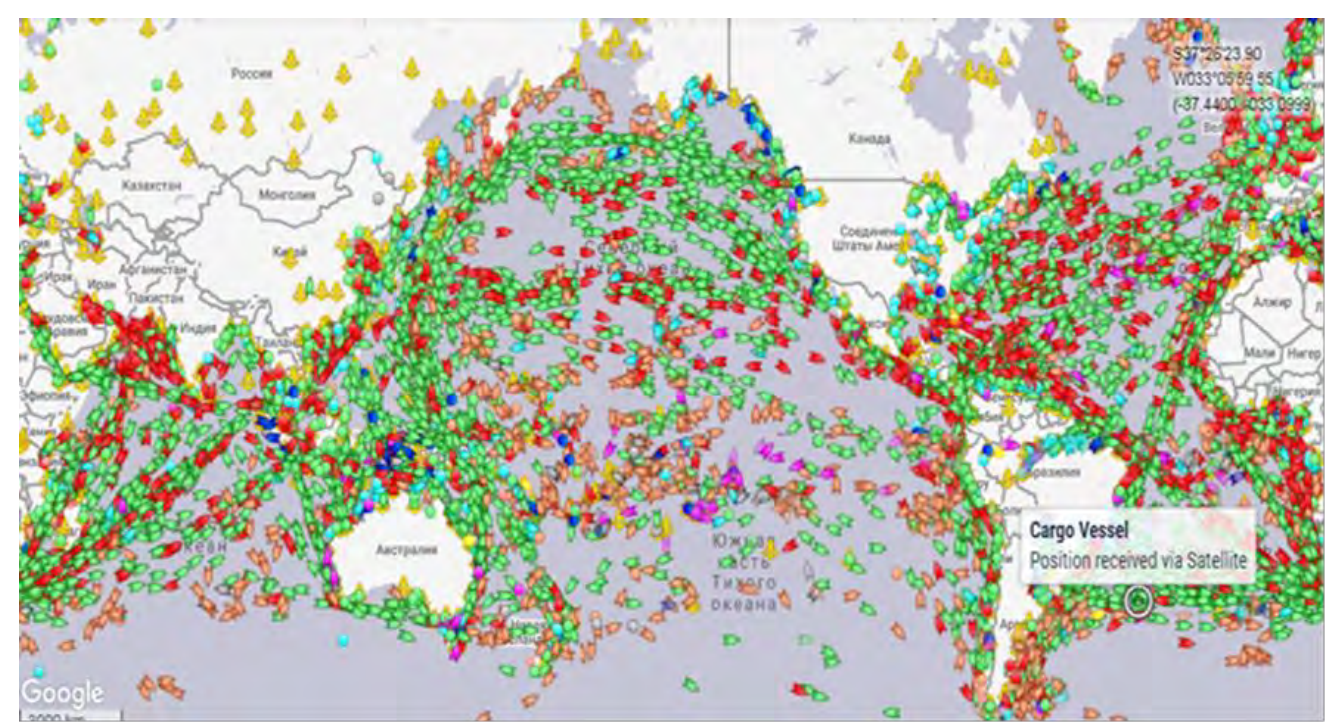

Figure 4 - Positions of ships at the current moment (2020).

Emission of dioxide of carbon at processing (incineration) settled accounts as general on equalization:

$$
\mathrm{e} \sum \mathrm{CO}_{2}=\mathrm{e}^{\mathrm{extr}} \mathrm{CO}_{2}+\mathrm{e}^{\text {tr. }} \mathrm{CO}_{2}+\mathrm{e}^{\text {proc. }} \mathrm{CO}_{2}+\mathrm{e}^{\text {comb }} \mathrm{CO}_{2},
$$

where $\mathrm{e}^{\text {extr }} \mathrm{CO}_{2}, \mathrm{e}^{\text {tr. }} \mathrm{CO}_{2}, \mathrm{e}^{\text {proc. }} \mathrm{CO}_{2}, \mathrm{e}^{\text {comb }} \mathrm{CO}_{2}$ are accordingly the total emission of carbon dioxide during the extraction of conditional fuel, its transportation, processing and combustion, $\mathrm{g} \mathrm{CO}_{2}-$ equivalent $/ \mathrm{kg}$ of conditional fuel, and as a result of only combustion of conditional fuel is $\mathrm{e}^{\mathrm{comb}} \mathrm{CO}_{2}$.

Results over of calculations are brought on a figure 5 .

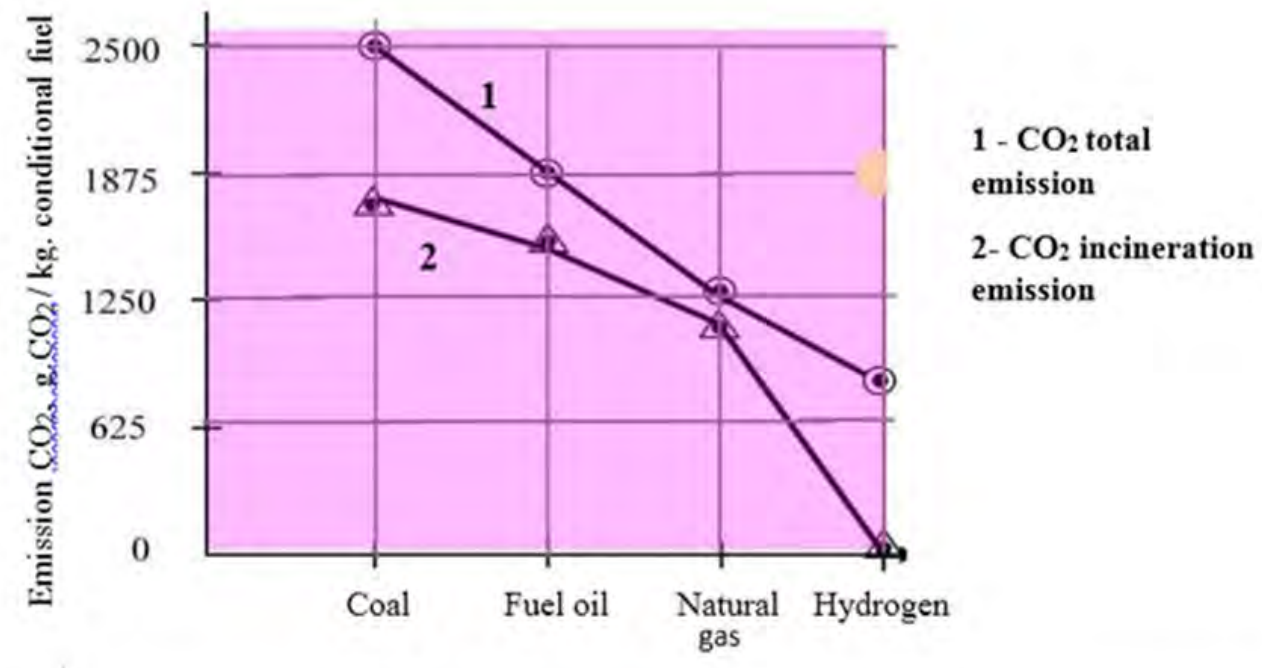

Figure 5. Emissions of carbon dioxide depending on the type of fuel burned 
From a Fig. 5 follows that emission of carbon dioxide, both general and only as a result of incineration, goes down in a row "coal $\rightarrow$ fuel oil $\rightarrow$ natural gas $\rightarrow$ hydrogen". As an oxidant when incineration of hydrocarbon raw materials was used the air.

In case of incineration of hydrogen in the stream of oxygen emission of dioxide of carbon at incineration is equal to the zero, and general emission of dioxide of carbon is equal $833 \quad \mathrm{~g} \quad \mathrm{CO}_{2} \quad-$ equivalent / $\mathrm{kg}$ of hydrogen (Fig. 5).

Resource-saving technologies allow, from one side, to bring down the specific consumption of hydrocarbon raw material per conditional ton of having special purpose products, and from other - to bring down the emission of material and level of energy wastes of the manmade systems.

Technical suggestions, that will allow to bring down emission of dioxide carbon and, accordingly, bring down the action of "greenhouse" effect, are below given:

1. Development and realization of low-waste, resource-saving technologies, allowing to bring down formation of material wastes and, as a result, bring down the emission of dioxide of carbon.

2. Extraction, concentration, collection, translation in the liquid aggregate state, storage and transporting of the liquefied dioxide of carbon.

3. Chemical conversion of dioxide carbon by the method of the catalytic hydrogenization in methanol ${ }^{15}$ and on the basis of methanol production of the plastic masses, urea-formaldehyde resins, hydrocarboxylic acids, fertilizers, pharmaceutical products, high-octane components of motor fuel, hydrogen, ethylene, protein-vitamin concentrate, hydrate inhibitor when mining of hydrocarbon gases.

In the Kherson State Marine Academy (a Scientific leader is professor Leonov V.Ye.) research, experienced and experienced-industrial works are conducted on development of resource-saving, ecologically safe technologies and use of nonhydrocarbon raw material for providing of functioning of the manmade systems.

A pool of the Black sea is the powerful source of unconventional energy resources, namely: the sulphuretted hydrogen and ground crystallohydrates. The ground crystallohydrates are a hard-phase alloy of ice and dissolved (adsorbed) hydrocarbons of $\mathrm{C}_{1}-\mathrm{C}_{5+}$. The Technical problem in the use of crystallohydrates consists of their extraction, transporting on the surface of

${ }^{15}$ Караваев М.М., Леонов В.Е., Попов И.Г., Шепелев Е.Т. Монография: Технология синтетического метанола. М.: Химия. 1984.- 240 с. 
marine environment ${ }^{16}$, and regasification and processing of crystallohydrates in compounds and motor fuel does not present industrial complications and can be realized in existent petrochemical complexes.

The hydrogen sulfide contained in the area of the Black sea presents an enormous potential danger for the countries of Black Sea Region ${ }^{17}$. The scientific and technical problems of deployment of the hydrogen sulfide for the production of motor fuels and compounds include the next stages ${ }^{18}$ :

- effective processing of the sulphuretted hydrogen in a motor fuel and chemical compounds.

We have been worked out an original technical decision on the deepwater marine of the sulphuretted hydrogen $(\approx 10000 \mathrm{~m})$. A decision is protected by the patent of Ukraine ${ }^{19}$.

By a technical decision ${ }^{20}$ a stationary marine platform, on that, collection, storage and preparation of the obtained sulphuretted hydrogen to the subsequent complex processing, comes true, is foreseen. The last comes true also on a marine platform.

The methods of processing of the sulphuretted hydrogen, sulfurcontaining compounds are offered by patent ${ }^{21}$ in valuable chemical compounds. Methods differs in high technical and economic indexes, namely, emission of harmful toxic components with exhaust gases of vessels engine in an atmosphere is fully absent.

\footnotetext{
${ }^{16}$ Леонов В.Е., Ходаковский В.Ф., Куликова Л.Б. Монография: Основы экологии и охрана окружающей среды./Под редакцией доктора технических наук, профессора В.Е. Леонова ./ Херсон:Херсонская государственная морская академия. 2010.-352 с.; Леонов В.Е., Ходаковский А.В. Учебное пособие: «Экология и охрана окружающей среды»./ Под редакцией доктора технических наук, профессора В.Е. Леонова ./ Херсон:Херсонская государственная морская академия./ 2016.-348 с.; Леонов В.Е., Чернявский В.В. Монография:Современные методы исследований и обработки экспериментальных данных / Под редакцией доктора технических наук, профессора В.Е. Леонова ./ Херсон:Херсонская государственная морская академия./ 2020.-520 с.

17 Там само

18 Леонов В.Е., Ходаковский А.В. Учебное пособие: «Экология и охрана окружающей среды»./ Под редакцией доктора технических наук, профессора В.Е. Леонова ./ Херсон:Херсонская государственная морская академия./ 2016.-348 с.; Леонов В.Е., Чернявский В.В. Монография:Современные методы исследований и обработки экспериментальных данных / Под редакцией доктора технических наук, профессора В.Е. Леонова ./ Херсон:Херсонская государственная морская академия./ 2020. 520 с.

19 Лєонов В.С., Гацан О.А. Гацан В.А. Плавучій комплекс для глибоководного видобутку сірководню із морськой води і спосіб запуску плавучого комплексу. Патент 92422 України, 2010.заявл. 25.10.2010: опубл. 23.08.2012, Бюл. № 31.

20 Там само

21 Леонов В.Е., Ходаковский В.Ф., Куликова Л.Б. Монография: Основы экологии и охрана окружающей среды./Под редакцией доктора технических наук, профессора В.Е. Леонова ./ Херсон:Херсонская государственная морская академия. 2010.-352 с.; Леонов В.Е., Ходаковский А.В. Учебное пособие: «Экология и охрана окружающей среды»./ Под редакцией доктора технических наук, профессора В.Е. Леонова ./ Херсон:Херсонская государственная морская академия./ 2016. 348 с.
} 
At a complex extraction and processing of the sulphuretted hydrogen of the Black Sea the basic problems of ecological safety, financial viability, resource-saving, defence of marine environment are deciding:

1) the potential danger of "breach" through the seawater of toxic, explosive and fire-hazardous hydrogen sulfide is reduced;

2) the dependence of countries on imports of hydrocarbon energy is reduced;

3) the socio-economic and environmental damage to the environment of the Black Sea countries is sharply reduced.

Based on the real state of affairs with stocks of hydrocarbon raw material, the time of their depletion, we can suggest three stages of transition from hydrocarbon raw material to nonhydrocarbon raw material:

1) remaining time of action and exploitation hydrocarbon raw material for providing of the manmade systems, to the requirements of resourcesaving;

2) transitional period, when the part of hydrocarbon raw material in general energy balance will make $50 \%$ and more, up to a complete substitution hydrocarbon raw material - on $100 \%$ nonhydrocarbon raw material;

3) set period of realization of nonhydrocarbon raw material for functioning of the manmade systems.

The completed epoch of hydrocarbon raw material is characterized by the substantial "change" of civilization toward unsteady development of society ${ }^{22}$. This instability is characterized by substantial influence of "greenhouse" effect, destruction of ozone layer of Planet and ecosystems, intensive exhausting of unrenewable and renewable energy, oxygen, natural fresh water sources.

As recommendations it is possible to offer next basic directions of activity within the framework of the first stage is hydrocarbon raw material:

1) "to preserve" further exploration, development and hydrocarbon production, to leave remaining hydrocarbon raw material to the future generations as reserve;

2) to transfer the manmade systems on resource-saving and ecologically safe technologies ${ }^{23}$;

\footnotetext{
22 Там само

23 Леонов В.Е., Ходаковский А.В. Учебное пособие: «Экология и охрана окружающей среды»./ Под редакцией доктора технических наук, профессора В.Е. Леонова ./ Херсон:Херсонская государственная морская академия./ 2016.-348 с.; Леонов В.Е., Чернявский В.В. Монография:Современные методы
} 
3) to reduce the manmade impact on the development of the "greenhouse" effect. On April 23, 2021, at the initiative of the US President, large-scale negotiations on the "climate" crisis were held, and the leaders of 40 leading countries of the world were invited. According to the Global Carbon Atlas, China, the USA, India, Russia, Japan, Iran,

Germany, Indonesia, and South Korea are the "leaders" in emissions of carbon dioxide, the main component of "greenhouse" gases. In the speeches of the leaders of the leading countries of the world, it was reported that by 2050 carbon dioxide emissions will decrease by $3-5$ times.

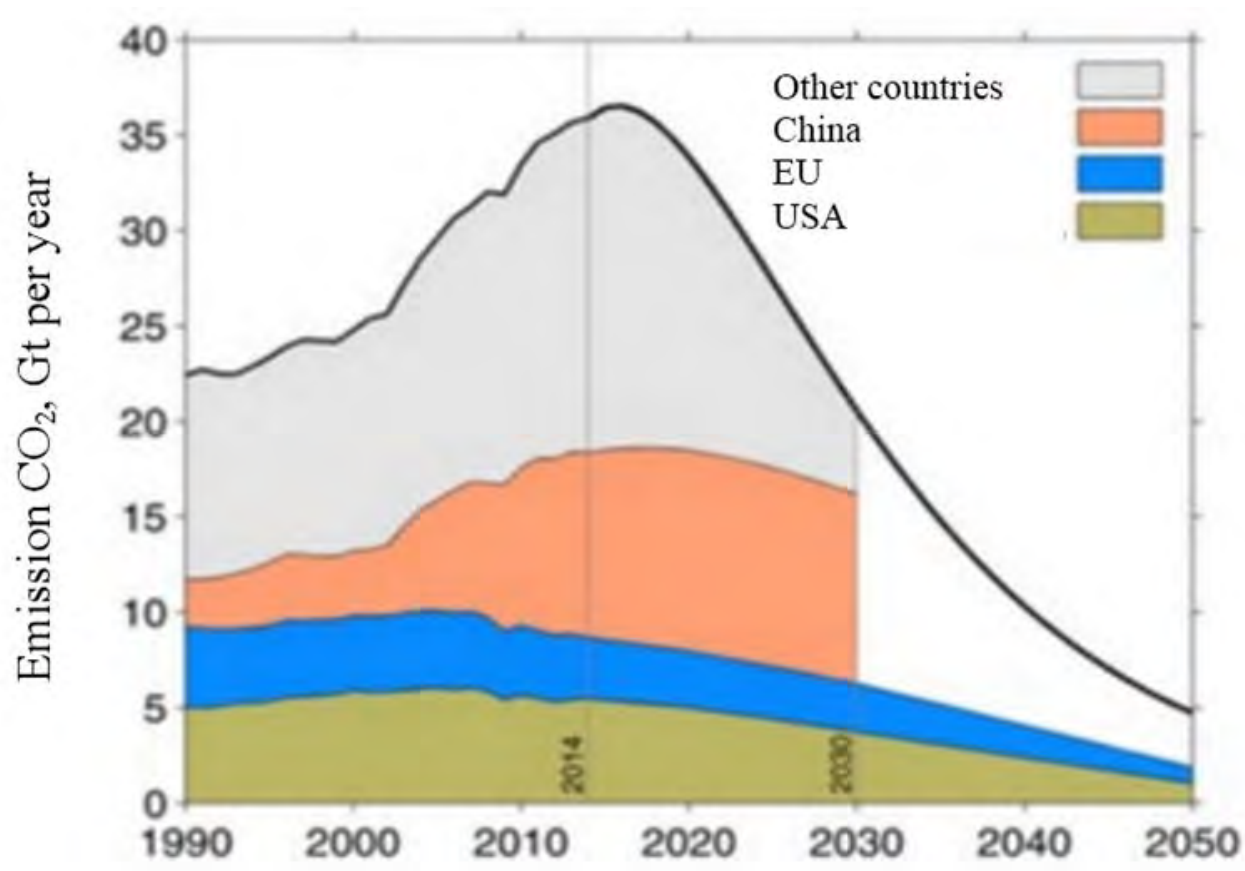

\section{Figure 6. Dependence of the emission of carbon dioxide into the air basin depending on the time ${ }^{24}$}

Figure 6 shows the dependence of the change in carbon dioxide emissions in general around the world and for individual countries for the period from 1990 to 2050 (Climate conference in Paris. 2015).

Figure 6 shows that the maximum emission of carbon dioxide, both in individual countries and around the world, falls on our time, 2015-2020, and by 2050, carbon dioxide emissions should decrease by more than seven times. This begs the question of how, on a global scale,

исследований и обработки экспериментальных данных / Под редакцией доктора технических наук, профессора В.Е. Леонова ./ Херсон:Херсонская государственная морская академия./ 2020. 520 с.

${ }^{24}$ Climate conference in Paris. 2015. http://www.un.org/sustainabledevelopment/ru/cop21/ 
carbon dioxide emissions can be reduced sevenfold. As we have shown (Fig. 5), it is practically impossible to achieve this within the framework of hydrocarbon energy, hydrocarbon raw materials (HCRM) of a nonrenewable nature. It remains to assume the change HCRM of the era to nonhydrocarbon feedstock (NHCFS). Depending on the adopted strategy, specific technical decisions will be made.

When extraction, storage, transporting of oil, and also at her processing in petrol, diesel, boiler fuel, fuel oil, besides casual and emergency losses, the systematic losses of hydrocarbons, conditioned by evaporation of liquid hydrocarbons from a surface at the "large" and "small" breathing in a capacity apparatus take place. The "large" breathing is emphasizing of air with the pairs of hydrocarbons from reservoirs when loading in its oils and light oil products. The "small" breathing of reservoirs is conditioned by the difference of temperatures of air on day and night. The general losses of hydrocarbons in the world reach of tens millions per year. A direct economic damage due to the losses of oil and oil products and ecologicaleconomic damage are thus inflicted because of contamination of air pool by hydrocarbons - the components of "greenhouse" gases.

The losses of hydrocarbons only at priming and storage of oil and oil products make a $1100 \mathrm{~g} / \mathrm{M}^{3}$ of airily-hydrocarbon mixture. According to the operating directives of the European Union the concentration of hydrocarbon in the vaporous state must not exceed a $35 \mathrm{~g} / \mathrm{m}^{3}$, i.e. the losses of hydrocarbon should reduce more than on 30 times by the requirements of European Union ${ }^{25}$.

For the decline of emission of hydrocarbons in atmosphere in the process of exploitation of tankers, gas carriers, chemical tankers, LPG carriers, innovative technical decisions are worked out to practical realization on a marine transport ${ }^{26}$.

\footnotetext{
25 Леонов В.Е., Ходаковский В.Ф., Куликова Л.Б. Монография: Основы экологии и охрана окружающей среды./Под редакцией доктора технических наук, профессора В.Е. Леонова ./ Херсон:Херсонская государственная морская академия. 2010.-352 с. ; Леонов В.Е., Ходаковский А.В. Учебное пособие: «Экология и охрана окружающей среды»./ Под редакцией доктора технических наук, профессора B.Е. Леонова ./ Херсон:Херсонская государственная морская академия./ 2016.-348 c. Leonov V., Gurov A. GREENHOUSE EFFECT. FICTION or RESULT of the PROLONGED ACTION of the TECHNOGENIC SYSTEMS. The Scientific Heritage : Hungary. 2021.- Vol. 1(60), p. 29-39. DOI: 10.24412/9215-0365-2021-60-1-29-29-39. https://www.elibrary.ru/item.asp?id=44726893

26 Леонов В.Е., Ходаковский В.Ф., Куликова Л.Б. Монография: Основы экологии и охрана окружающей среды./Под редакцией доктора технических наук, профессора В.Е. Леонова ./ Херсон:Херсонская государственная морская академия. 2010.-352 с.; Леонов В.Е., Ходаковский А.В. Учебное пособие: «Экология и охрана окружающей среды»./ Под редакцией доктора технических наук, профессора В.Е. Леонова ./ Херсон:Херсонская государственная морская академия./ 2016.-348 с.; Леонов В.Е., Чернявский В.В. Монография:Современные методы исследований и обработки
} 
When hydrocarbons are emitted into the atmospheric basin, economic damage is caused during the transportation of oil products and environmental damage to the air basin. Below is a logistic scheme for the transportation of oil, its processing into "light" oil products and refueling of vehicle engines, from which it follows that in the case of absorption of hydrocarbons after the capacitive equipment, the emission of hydrocarbons into the air basin decreases 30 times compared with the option without absorption of hydrocarbons .

To reduce the emission of hydrocarbons into the atmosphere during the operation of tankers, gas carriers, chemical gas carriers, methane carriers, innovative technical solutions have been developed for practical implementation in sea transport ${ }^{27}$.

To select the most effective technology, we carried out research using the following methods of absorption of hydrocarbons from steam-air mixtures:

1) absorption;

2) adsorption;

3) catalytic;

4) low temperature condensation;

5) homogeneous oxidation of hydrocarbons at elevated temperatures.

Based on the performed feasibility studies of the above methods of absorption of hydrocarbons in comparable conditions, it was determined that the most effective method in this case is adsorption (point 2).

Three versions of the technology for absorption of hydrocarbons from gas-air environ have been developed for "large" and "small" breathing of reservoirs. The choice of this or that technology depends on the volume of supplied oil and light oil products, design features and hardware design of a particular facility. The technologies have been tested in pilot industrial conditions.

The technology of hydrocarbon absorption by the adsorption method has been developed (Fig. 7).

\footnotetext{
экспериментальных данных / Под редакцией доктора технических наук, профессора В.Е. Леонова ./ Херсон:Херсонская государственная морская академия./ 2020. 520 с.

27 Леонов В.Е., Ходаковский А.В. Учебное пособие: «Экология и охрана окружающей среды»./ Под редакцией доктора технических наук, профессора В.Е. Леонова ./ Херсон:Херсонская государственная морская академия./ 2016.-348 с.; Леонов В.Е., Чернявский В.В. Монография:Современные методы исследований и обработки экспериментальных данных / Под редакцией доктора технических наук, профессора В.Е. Леонова ./ Херсон:Херсонская государственная морская академия./ 2020.-520 с.
} 


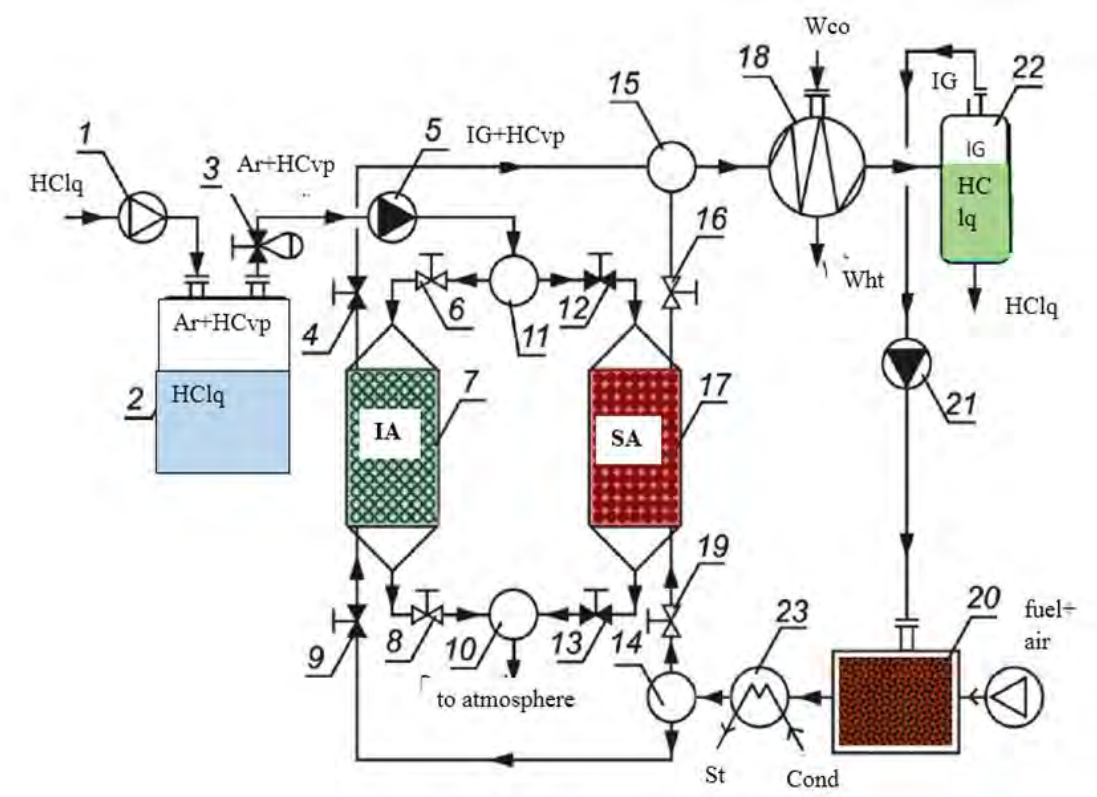

Figure 7. Schematic diagram of vapor recovery hydrocarbons.

Equipment explication: 1 - pump; 2 - storage; 3 - reducer; 4, 9, 12, 13 - shut-off valves in the closed position; 5, 21 - compressor; $6,8,16,19$ - shut-off valves in open position; 7 - adsorber in absorption mode; 10, 11, 14, 15 - mixer-distributor; 17 - adsorber in the regeneration mode; 18 - condenser refrigerator; 20 - installation for inert gas production; 22 - separator; 23 - heat exchanger;

Legend: HCliq is the liquid hydrocarbons; HCvp is the hydrocarbons in vapor phase; Ar is the air; IG is the inert gas; $\mathrm{T}$ is the fuel; Wco, Wht are respectively the cooling and heated water; IA is the initial adsorbent for absorption of hydrocarbons; SA is the adsorbent saturated with $\mathrm{HC}_{\mathrm{v}}$; $\mathrm{St}$ is the steam; Cond is the condensate.

The technology includes the following main stages:

1. Collection and compression of the air-hydrocarbon mixture outgoing from the storage pos. 2

2. Adsorption of hydrocarbons vapors in the adsorber pos. 7.

3. Regeneration of the saturated adsorbent in the adsorber pos. 17 in an inert gas stream at increased temperature.

4. Cooling of hydrocarbons vapors in the refrigerator-condenser pos. 18

5. Separation of inert gas and liquid hydrocarbons in the separator pos. 22.

6. Return of inert gas after separator pos. 22 in the regeneration cycle.

7. Return of gasoline (liquid hydrocarbons) to the storage pos. 2. 
The developed hydrocarbon absorption scheme is resource-saving and environmentally safety. This is especially becoming relevant at the present time, since the world's reserves of non-renewable hydrocarbon raw materials are intensively depleted and limited, dangerous for the environment, biosphere and humans.

Hydrocarbon vapors released from storage 2 are absorbed by the adsorbent in adsorber 7 . The saturated hydrocarbon adsorbent is regenerated in adsorber 17 in an inert gas (IG) flow at a temperature of 65$80{ }^{\circ} \mathrm{C}$. As a result of the regeneration, hydrocarbon separated from the adsorber 17 are condensed upon cooling in the refrigerator-condenser 18 , collected in the separator 22, in which they are separated into liquid B and gaseous IG phases. Further on, the adsorber 7 operates in the regeneration mode, and the adsorber 17 - in the hydrocarbon absorption mode.

The developed technology is intended directly for functioning on board of the vessel and allows, in comparison with the known technical proposals, to solve the following main topical issues of shipping:

1. Use cheap heavy fuel on board IFO 180.-380 (3,5\% weight "S").

2. To increase the economic indicators of the vessel, voyage due to the utilization of the heat of the exhaust gas of the ship power plant and the receipt of target products.

3. Ensure the ecological safety of the sea environment during the operation of ships, regardless of its project, type, cargo and route.

Thus, as a result of the developed technology for the purification and utilization of the heat of the exhaust gases of the SPP, the following environmental and economic problems of navigation are solved:

1. The use of cheap high-sulfur diesel fuel on board a vessel for sea cargo transportation in the areas of special control of SECA, ECA, and from 01.01.2020 - all over the world.

2. Ensuring the sanitary cleaning of the EG of SPP to a safe level for all toxic components and, in particular, for sulfur compounds and solid particles (soot deposits).

3. Implementation of a comprehensive deep utilization of the heat of exhaust gases from the ship power plant and their cleaning.

4. Obtaining target marketable products and heat from the exhaust gases of the SPP after their sequential processing directly on board the ship.

5. To increase the economic efficiency of sea cargo transportation, the efficiency of the vessel / voyage, to ensure the protection of the marine environment.

6. The payback period of a complex resource-saving technological unit does not exceed three years. 
7. The analysis, generalization of technical solutions for the purification of exhaust gases were conducted, as a result of the technical and economic analysis of the technological scheme, it should be concluded that the developed technological scheme has undeniable advantages ${ }^{28}$ in comparison with the systems of exhaust gas of SPP heat recovery implemented in practice.

\section{Discussion}

When $1 \mathrm{~m}^{3}$ of air is displaced, $1 \mathrm{~kg}$ of gasoline vapor is lost. Let's take the storage volume of $1000 \mathrm{~m}^{3}$, then the gasoline losses during one refueling-delivery will be:

$1 \mathrm{~kg} \cdot 1000 \cdot 2=2000 \mathrm{~kg}=2$ tons of gasoline.

With 100 refueling gasoline losses will be: $1.19 \cdot 200000 / 0.743=320$ 323 USD,

where 0.743 is the density of gasoline, $\mathrm{kg} / \mathrm{l}$;

1.19 - the price of 1 liter of AI-95 gasoline, USD.

Economic efficiency from the implementation of a gasoline vapor recovery unit with an absorption rate of $95 \%$ is: $320323 \times 0.95=304307$ USD.

The technology for capturing hydrocarbon vapors complies with the Kyoto Protocol on 1997 (Japan), Paris Agreement COP-21 (2015) on the reduction of emissions of "greenhouse" gas components.

Below are the results of studies to reduce the consumption of marine fuel, leading to a decrease in carbon dioxide emissions, and, as a consequence, to a decrease in the intensity of the "greenhouse" effect.

In work ${ }^{29}$, it was shown for the first time that if oxygen is used instead of air as an oxidizing agent for marine fuel on a ship, then the share of perfect useful work will double and the emission of nitrogen oxides will be

\footnotetext{
${ }^{28}$ H.-N. Su, I.M.Moaniba. Does innovation respond to climate change? Empirical evidence from patents and greenhouse gas emissions. Technological Forecasting and Social Change. 2017. Vol. 122, P. 49-62. doi:10.1016/j.techfore.2017.04.017; V.Ramanathan, Y.Feng. Air pollution, greenhouse gases and climate change: Global and regional perspectives. Atmospheric Environment 2009.-Vol. 43, Issue 1, P. 37-50. DOI:10.1016/j.atmosenv.2008.09.063; Леонов В.Е., Чернявский В.В. Монография:Современные методы исследований и обработки экспериментальных данных / Под редакцией доктора технических наук, профессора В.Е. Леонова ./ Херсон:Херсонская государственная морская академия./ 2020.-520 c. ISBN 978-966-2245-60-8. ; Leonov V., Gurov A. GREENHOUSE EFFECT. FICTION or RESULT of the PROLONGED ACTION of the TECHNOGENIC SYSTEMS. The Scientific Heritage : Hungary. 2021. Vol. 1(60), P. 29-39. DOI: 10.24412/9215-0365-2021-60-1-29-29-39. https://www.elibrary.ru/ item.asp?id=44726893; Концентрация $\mathrm{CO}_{2}$ в атмосфере вокруг Японии побила рекорд. Российская газета. 30.03.2021.

29 Леонов В.Е., Гуров А.А.Использование кислорода в качестве окислителя судового топлива вместо воздуха для судовых энергетических установок. Вестник Государственного Университета Морского и Речного Флота имени адмирала С.О. Макарова. 2020. Том 12. № 3, С. 770-782. DOI: $10.21821 / 2309-5180-2020-12-3-770-782$.
} 
completely eliminated, the metal consumption of the main power plant and heat losses will decrease by five times. The main question that must be resolved is how to obtain oxygen economically. At present, the technologies for producing oxygen from air have been mastered in industry. The disadvantages of these methods are

high material and energy costs, capital investments, long payback period, low frequency of air reserves. The new method of oxygen production proposed by us is focused on the use of water and carbon dioxide as a feedstock, which have a high multiplicity of reserves of $10^{12}-10^{15}$. Oxygen production is carried out in accordance with patents of Ukraine ${ }^{30}$.

Studies have been carried out to minimize the Energy Efficiency Operational Index of a vessel (EEOI) when performing a real, regular voyage Operational ${ }^{31}$.

As a result of the research, it was determined that the consumption of marine fuel can be reduced by $35-50 \%$ by changing the load on the power plant, the speed, the distance of passage, the weight of the cargo.

Hydrogen energy - from Figure 5 it follows that the transition of technogenic systems to hydrogen fuel will eliminate the emission of carbon dioxide, reduce the intensity of the growth of the "greenhouse" effect, the risk of a "climatic" crisis. We are developing a technology for producing oxygen and hydrogen from water ${ }^{32}$.

Carbon dioxide, marine crystalline hydrates and hydrogen sulfide non-hydrocarbon raw materials - are considered as sources for obtaining energy fuel, electricity, chemicals and organic synthesis products ${ }^{33}$.

\footnotetext{
${ }^{30}$ Лєонов В.Є.Патент на корисну модель «Спосіб отримання кисню, що викорисовується для суднових енергетичних установок». Патент України на корисну модель № 140059 від 10.02.2020. Опубликовано 10.02.2020. Бюл.№ 3.; Лєонов В.С., Чернявський В.В. Патент на корисну модель «Застосування кисню як окислювача суднового палива». Патент України на корисну модель № 147193 від 12.10.2020 Опубликовано 21.04.2021. Бюл.№ 16.

31 Леонов В.Е. Исследование по определению области минимизации ЕЕОІ судна. С-Пб:Вестник государственного университета морского и речного флота имени адмирала С.О. Макарова. 2019. Том 11. № 5 (57). С. 910-919. DOI: 10.21821/2309-5180-2019-11-5-910-919.

${ }^{32}$ Лєонов В.С.Патент на корисну модель «Спосіб отримання кисню, що викорисовується для суднових енергетичних установок». Патент України на корисну модель № 140059 від 10.02.2020 .Опубликовано 10.02.2020. Бюл.№ 3; Лєонов В.С., Чернявський В.В. Патент на корисну модель «Застосування кисню як окислювача суднового палива». Патент України на корисну модель № 147193 від 12.10.2020 Опубликовано 21.04.2021. Бюл. № 16.

33 Леонов В.Е., Ходаковский В.Ф., Куликова Л.Б. Монография: Основы экологии и охрана окружающей среды./Под редакцией доктора технических наук, профессора В.Е. Леонова ./ Херсон:Херсонская государственная морская академия. 2010.-352 с. Леонов В.Е., Ходаковский А.В. Учебное пособие: «Экология и охрана окружающей среды»./ Под редакцией доктора технических наук, профессора В.Е. Леонова ./ Херсон:Херсонская государственная морская академия./ 2016. 348 с.; Леонов В.Е., Чернявский В.В. Монография:Современные методы исследований и обработки
} 


\section{CONCLUSION}

Thus, as a result of the work performed, the following conclusions can be drawn:

1. Losses of hydrocarbons during transportation and storage of petroleum products have two negative vectors - economic and environmental.

2. Research on the absorption of hydrocarbon vapors under static and dynamic conditions has been carried out.

3. Resource-saving technologies for absorption of hydrocarbons from vapor-air environ have been developed.

4. Experimental-industrial tests of the hydrocarbon absorption process were carried out.

5. The technical and economic considerations of the expediency of introducing the technology for the utilization of hydrocarbon vapors have been developed.

6. In the case of using hydrocarbon raw materials, it is necessary to solve the problem of reducing carbon dioxide emissions by reducing the consumption of hydrocarbon fuel and utilizing carbon dioxide.

7. With read expedient and timely transition to non-hydrocarbon raw materials - water, carbon dioxide, sea bottom crystalline hydrates, hydrogen sulfide with the receipt of electricity, hydrogen, chemicals, organic synthesis products from them.

\section{SUMMARY}

Despite the contradictory views on the "greenhouse" effect, it can be stated that the consequences of an increase in the average annual temperature of the air basin and the marine oceanic environment are very negative and predictably catastrophic. We have carried out an analysis and computational studies over the past 60 years, characterized by the most intensive consumption of hydrocarbon raw materials of a non-renewable nature, by the accumulation of carbon dioxide, a marker of the "greenhouse" effect.

The examples of the implementation of research work to reduce the emission of components of "greenhouse" gases in marine transport, which

\footnotetext{
экспериментальных данных / Под редакцией доктора технических наук, профессора В.Е. Леонова ./ Херсон:Херсонская государственная морская академия./ 2020. 520 с. ISBN 978-966-2245-60-8; Караваев М.М., Леонов В.Е., Попов И.Г., Шепелев Е.Т. Монография: Технология синтетического метанола. М.: Химия. 1984. 240 с.
} 
will solve the two-vector task - to increase the economic efficiency of sea freight and ensure the environmental safety of sea freight.

\section{REFERENCES}

1. Леонов В.Е., Ходаковский В.Ф., Куликова Л.Б. Монография: Основы экологии и охрана окружающей среды./Под редакцией доктора технических наук, профессора В.Е. Леонова. Херсон : Херсонская государственная морская академия. 2010. 352 с.

2. Леонов В.Е., Ходаковский А.В. Учебное пособие: «Экология и охрана окружающей среды» / Под редакцией доктора технических наук, профессора В.Е. Леонова. Херсон : Херсонская государственная морская академия. 2016. 348 с.

3. Изменение климата достигло катастрофических масштабов. 2021. https://news.rambler.ru/tech/45673808 - izmenenie-klimata dostig.

4. Содержание углекислого газа в атмосфере Земли значительно выросло. Деловая газета “Взгляд”.2019.URL

5. Hensher DA, Faqhimnia V. Green logistics and Transportation. Greening of Industry Networks Studies 4. Springer International Publishing Switzerland. 2015. Vol. 65(3), p. 131-145.

6. Thalis ZisH., Angeloudis and Michel G.H. Bell. Economic and Environmental Trade-Offs in Water Transportation. Springer International Publishing Switzerland. 2015. Vol. 65(3). p. 159-165.

7. Романов Е.В., Лелецкий А.В., Лабунин К.А. Парниковый эффект: принципы, последствия, способы оптимизации. Орел : Вестник Орловского государственного университета имени И.С. Тургенева. 2019. С. 13-18. URL- cyberleninka.ru.

8. Lee Chapman. Transport and climate change: a review. Journal of Transport Geography.2007.- Vol.15, Iss.5, P. 354-367. doi:10.1016/j.jtrangeo.2007.11.008

9. Klaus Eisenack, Rebecca Stecker, Diana Reckien \& Esther Hoffmann .Adaptation to climate change in the transport sector: a review of actions and actors. Mitigation and Adaptation Strategies for Global Change. 2012.- Vol 17, p. 451-469.

10. MEPC 65/INF.17. IMO Model Course on Energy-Efficient Operation of Ships. London: World Maritime University. 2013.61 p.

11. Su H.-N., Moaniba I.M. Does innovation respond to climate change? Empirical evidence from patents and greenhouse gas emissions. 
Technological Forecasting and Social Change. 2017. Vol. 122, P. 49-62. doi:10.1016/j.techfore.2017.04.017

12. Ramanathan V., Feng Y. Air pollution, greenhouse gases and climate change: Global and regional perspectives. Atmospheric Environment 2009.-Vol. 43, Issue 1, P. 37-50. DOI:10.1016/ j.atmosenv.2008.09.063

13. Леонов В.Е., Чернявский В.В. Монография: Современные методы исследований и обработки экспериментальных данных / Под редакцией доктора технических наук, профессора В.Е. Леонова ./ Херсон:Херсонская государственная морская академия. 2020. 520 с.. ISBN 978-966-2245-60-8. URL

14. Leonov V., Gurov A. GREENHOUSE EFFECT. FICTION or RESULT of the PROLONGED ACTION of the TECHNOGENIC SYSTEMS. The Scientific Heritage : Hungary. 2021. Vol. 1(60), p. 29-39. DOI: 10.24412/9215-0365-2021-60-1-29-29-39. https://www.elibrary.ru/item.asp?id=44726893

15. Концентрация СО2 в атмосфере вокруг Японии побила рекорд. Российская газета. 30.03.2021. URL

16. Караваев М.М., Леонов В.Е., Попов И.Г., Шепелев Е.Т. Монография: Технология синтетического метанола. Москва : Химия. 1984. $240 \mathrm{c}$.

17. Лєонов В.С., Гацан О.А. Гацан В.А. Плавучій комплекс для глибоководного видобутку сірководню із морськой води і спосіб запуску плавучого комплексу. Патент 92422 України, 2010.заявл. 25.10.2010: опубл.. 23.08.2012, Бюл. № 31.

18. Climate conference in Paris. 2015. http://www.un.org/ sustainabledevelopment/ru/cop21/

19. Леонов В.Е., Гуров А.А.Использование кислорода в качестве окислителя судового топлива вместо воздуха для судовых энергетических установок. Вестник Государственного Университета Морского и Речного Флота имени адмирала С.О. Макарова. 2020. Том 12. № 3, с. 770-782. DOI: 10.21821/2309-5180-2020-12-3-770-782.

20. Лєонов В.С.Патент на корисну модель «Спосіб отримання кисню, що викорисовується для суднових енергетичних установок» . Патент України на корисну модель №140059 від 10.02.2020. Опубликовано 10.02..2020. Бюл. № 3.

21. Лєонов В.С., Чернявський В.В. Патент на корисну модель «Застосування кисню як окислювача суднового палива». Патент 
України на корисну модель № 147193 від 12.10.2020. Опубликовано 21.04.2021. Бюл. №16

22. Леонов В.Е. Исследование по определению области минимизации EEOI судна. Санкт-Петербург : Вестник государственного университета морского и речного флота имени адмирала С.О. Макарова. 2019.-Том 11. № 5 (57). С. 910-919. DOI: $10.21821 / 2309-5180-2019-11-5-910-919$.

Information about the author: Leonov Valeriy Yevhenovych, Doctor of Technical Sciences, Professor, Full Member of the International Academy "Ecoenergy", Ship Handling Department, Kherson State Maritime Academy 20, Ushakova Avenue, Kherson, 73000, Ukraine 